\title{
Recombinant Interleukin-12 Suppresses the Synthesis of Immunoglobulin E by Interleukin-4 Stimulated Human Lymphocytes
}

\author{
M. Kiniwa, ${ }^{\star}$ M. Gately, ${ }^{\ddagger}$ U. Gubler, ${ }^{\ddagger}$ R. Chizzonite, ${ }^{\star}$ C. Fargeas, ${ }^{\star}$ and G. Delespesse ${ }^{\star}$ \\ *University of Montreal, Notre-Dame Hospital Research Center, Montreal, Quebec H2L 4M1, Canada; \\ and ${ }^{\ddagger}$ Hoffmann La Roche Inc., Nutley, New Jersey 07110
}

\begin{abstract}
Interleukin-12 is a recently discovered lymphokine displaying an array of in vitro activities suggesting a major role in protective immunity against infectious agents like viruses. This study provides evidence that IL-12 may also be implicated in the selection of the immunoglobulin isotypes. We show that picomolar concentrations of rIL-12 markedly inhibit the synthesis of IgE by IL-4-stimulated PBMC. The suppression of $\mathrm{IgE}$ is observed at the protein and at the mRNA levels, it is isotype specific, and it is abolished by neutralizing anti-IL-12 mAbs. IL-12 may suppress IgE synthesis by: $(a)$ inducing the production of IFN- $\gamma$, a known inhibitor of IgE synthesis and (b) by a novel mechanism which is IFN- $\gamma$ independent. The best evidence for this is from studies on IgE synthesis by IL-4-plus hydrocortisone-stimulated umbilical cord blood lymphocytes, which do not produce detectable amounts of IFN- $\gamma$. In such cultures, rIL-12 inhibits IgE synthesis even in the presence of a large excess of neutralizing anti-IFN- $\gamma \mathrm{mAb}$. (J. Clin. Invest. 1992. 90:262-266.) Key words: IgE • IL-12 • $\mathrm{\epsilon mRNA} \cdot$ IFN- $\gamma$
\end{abstract}

\section{Introduction}

In vivo and in vitro observations have demonstrated that the synthesis of $\operatorname{IgE}$ is dependent upon the balance between the production of IL- 4 and IFN- $\gamma$ at the sites of T/B cell interactions (1-3). IL-4 may promote IgE synthesis not only via a direct effect on B cells, resulting in switching to IgE (4-5), but perhaps also by regulating the production of other molecules or cytokines involved in IgE regulation. For example, IL-4 markedly inhibits IFN- $\gamma$ production by human lymphocytes stimulated by mitogen or allogeneic cells (6-7). In addition, IL-4 may also be involved in directing the differentiation of naive precursor T cells into TH 2 type of effector cells, producing IL-4 but not IFN- $\gamma(8)$. Similarly, IFN- $\gamma$ suppresses the in vivo synthesis of IgE, not only by antagonizing the effect of IL-4 on the switching to IgE, but perhaps also by inhibiting the proliferation of IL-4-producing TH2 lymphocytes $(9,10)$, or by directing the differentiation of naive precursor $\mathrm{T}$ cells into $\mathrm{T}$ cells

Address correspondence to Dr. G. Delespesse, University of Montreal, Notre-Dame Hospital, 1560 Sherbrooke Street East, Montreal, Quebec H2L 4M1 Canada.

Received for publication 5 February 1992 and in revised form 4 April 1992.

J. Clin. Invest.

(C) The American Society for Clinical Investigation, Inc.

0021-9738/92/07/0262/05 \$2.00

Volume 90, July 1992, 262-266 producing IFN- $\gamma$ but not IL-4 (11). Lymphokines other than IL-4 and IFN- $\gamma$ may also have an important role in the regulation of IgE synthesis. Interferon- $\alpha$, a cytokine mainly produced by accessory cells, is a potent inhibitor of the in vitro and in vivo synthesis of mouse and human $\operatorname{IgE}(1,3)$. IFN- $\alpha$ also counteracts the effect of IL-4 on the switching to IgE, and most interestingly, as IFN- $\gamma$ does, it inhibits the in vivo production of IL-4 and enhances that of IFN- $\gamma$ (12). Interleukin-12 is a novel cytokine which, like IFN- $\gamma$ and IFN- $\alpha$, may be involved in protective immunity against infectious agents such as viruses (13-17). Previously known as NKSF (natural killer cell stimulatory factor) or as CLMF (cytotoxic lymphocyte maturation factor), IL-12 is a 75-kD heterodimeric glycoprotein displaying several in vitro activities including: ( $a$ ) enhancement in synergy with IL2, of the generation of cytotoxic T cells and of lymphokine-activated killer cells (13); $(b)$ increase in the cytotoxic activity of natural killer (NK) cells (15); (c) promotion of the proliferation of activated T cells and NK cells $(16)$ and; $(d)$ induction of IFN- $\gamma$ production by resting or activated peripheral blood NK cells and T cells (17). Here we report that IL-12 is a strong inhibitor of the T cell-dependent synthesis of IgE by IL-4-stimulated peripheral blood mononuclear cells and that this inhibition may be observed in the absence of IFN- $\gamma$ production.

\section{Methods}

Reagents. Human rIL-4 was a gift of Dr. H. Hofstetter (CIBA-GEIGY, Basel, Switzerland); anti-CD40 mAb 89 (18) was received from Dr. J. Banchereau (Schering Plough, Dardilly, France); hydrocortisone was obtained from Sigma Chemical Co., St. Louis, MO; PWM was from Gibco Laboratories, Grand Island, NY; anti-IFN- $\gamma$ neutralizing mAb (No. 1598-00) was purchased from Genzyme Corp., Boston, MA. In preliminary titration experiments, this antibody $(25 \mu \mathrm{g} / \mathrm{ml})$ completely neutralized the suppressive activity of $500 \mathrm{IU} / \mathrm{ml}$ of IFN- $\gamma$ on the IL-4-stimulated synthesis of IgE by PBMC (IgE, $\mathrm{ng} / \mathrm{ml}$ in IL-4-stimulated cultures $30 \pm 4$, as compared to $9.8 \pm 2$ in the presence of IFN- $\gamma$ [500 IU/ml], and to $31.7 \pm 3.8$ in the presence of both IFN- $\gamma$ and antiIFN- $\gamma \mathrm{mAb}$ ). Anti-Lolpl $\mathrm{mAb}$ is a mouse IgGl antibody directed against the pollen antigen Lolp1 (19).

Human $r I L-12$ and antibodies to $I L-12$. Human rIL-12 was produced by cotransfection of COS cells with a 1:1 molar ratio of the two subunit cDNAs of IL-12 as described by Gubler et al. (13). Crude supernatant fluid from cultures of doubly transfected cells was used as the source of rIL-12 in these experiments. Supernatant fluid from cultures of mock transfected COS cells was used as a control. Monoclonal antiIL-12 antibody was a 1:1 mixture of two rat monoclonal anti-human IL-12 antibodies, $4 \mathrm{~A} 1$ and $20 \mathrm{C} 2$, which were isolated and purified as

1. Abbreviations used in this paper: $\mathrm{HC}$, hydrocortisone; NK, natural killer (cells). 
previously described (20). The 4Al antibody is specific for the $40-\mathrm{kD}$ subunit of human IL-12, and its isotype is IgG2b. The $20 \mathrm{C} 2$ antibody reacts with the $35-\mathrm{kD}$ subunit of IL-12, and its isotype is IgG1. These two antibodies were previously found to synergize in blocking IL-12-stimulated proliferation of human PHA-activated lymphoblasts (Gately, M., unpublished results). Purified myeloma rat IgG1 and IgG2b (Zymed Laboratories, San Francisco, CA) were used as isotypematched controls.

Cell preparations and culture conditions. Cells were prepared and cultured as described $(19,21)$. Briefly, PBMC were isolated from heparinized venous blood of healthy individuals by centrifugation over Ficoll-Metrizoate. Umbilical cord blood was collected in heparin-containing tubes and was sedimented $45 \mathrm{~min}$ at $37^{\circ} \mathrm{C}$ with dextran $(10 \%$ vol/vol; mol wt 200, J. T. Baker Chemical Co., Phillipsburg, NJ); the leukocyte-rich plasma was then layered on Ficoll-Metrizoate. Cells were cultured in HB101 culture medium (Hana Biologics, Alemeda, CA) supplemented with 5\% FCS (Flow Laboratories, Inc., McLean, VA), penicillin $(100 \mathrm{U} / \mathrm{ml})$, streptomycin $(100 \mu \mathrm{g} / \mathrm{ml})$, L-glutamine $(2$ $\mathrm{mM}$ ) (Gibco Laboratories), sodium pyruvate (10 mM), and Hepes (10 $\mathrm{mM})$. Cells $\left(2 \times 10^{5}\right.$ in $\left.0.2 \mathrm{ml}\right)$ were cultured in four replicates or more in round-bottomed 96-well tissue culture plates (Linbro, Flow Laboratories, Hamden, CT) for $12 \mathrm{~d}$ in a humidified atmosphere of $5 \% \mathrm{CO}_{2}$ and $95 \%$ air. For the induction of IgE synthesis, cultures were supplemented with IL-4 at the final concentration of $10 \mathrm{ng} / \mathrm{ml}$. This concentration was found to be optimal for the induction of $\operatorname{IgE}$ synthesis and the suppression of IFN- $\gamma$ production in mixed lymphocyte cultures.

RIAs. Immunoglobulins were measured in cell-free culture supernatants by means of solid phase RIAs exactly as described $(19,21)$. IFN- $\gamma$ was measured by a commercially available RIA (Centocor Co., Malvern, PA) with a sensitivity of $1 \mathrm{IU} / \mathrm{ml}$. The net synthesis of Igs and of IFN- $\gamma$ was determined by subtracting the values measured in the culture supernatants of cycloheximide-treated cells $(50 \mu \mathrm{g} / \mathrm{ml})$ from those of untreated cells. In preliminary experiments where the levels of IFN- $\gamma$ in the supernatants of IL-12-stimulated cultures were determined at $\mathrm{d} 2,4,6$, and 8 , we found, in agreement with a previous report (17), that a plateau was obtained between $d 4$ and 6 . IFN- $\gamma$ was therefore routinely measured on $\mathrm{d} 6$. To this end, $50 \mu \mathrm{l}$ of culture supernatants were collected and replaced by the same volume of fresh culture medium. All the culture supernatants were stored at $-20^{\circ} \mathrm{C}$ until the assay.

Northern blot analysis. Northern blot analysis was carried out exactly as described (6). Briefly, total RNA was extracted from cultured PBMC by the guanidinium-thiocyanate method with $\mathrm{CsCl}$ gradient modification and quantified by measurement of absorbance at 260 $\mathrm{nm}$. The samples ( $20 \mu \mathrm{g}$ per lane) were subjected to electrophoresis in formaldehyde-containing $1 \%$ agarose gel, and transferred to nylon membrane (Biotrans; ICN, Irvine, CA). The membrane was baked $2 \mathrm{~h}$ at $80^{\circ} \mathrm{C}$ under vacuum, prehybridized in $50 \%$ formamide $/ 5 \times$ Denhardt's $/ 5 \times$ standard saline citrate $/ 10 \mathrm{mM}$ EDTA $/ 50 \mathrm{mM}$ sodium phosphate $\mathrm{pH} 6.8 / 0.1 \% \mathrm{SDS} / 250 \mu \mathrm{g} / \mathrm{ml}$ salmon sperm DNA, and incubated overnight at $42^{\circ} \mathrm{C}$ with ${ }^{32} \mathrm{P}$-labeled cDNA probe in the same buffer. The probes used for the detection of the germ-line and the mature form of $C_{\epsilon}$ mRNA were kindly provided by Dr. R. Geha and described by Jaraba et al. (22). A 0.74-kb Smal fragment overlapping the germline exon was used to detect germ-line $\mathrm{C}_{\epsilon}$ transcript, and the 0.88-kb Hinfl fragment encompassing most of the $C \epsilon 1$ exon and the totality of the $\mathrm{C} \epsilon 2$ exon was used to detect both the productive and the germ-line $C \epsilon$ mRNAs.

\section{Results}

Given that IL-12 and IL-4 are known to have opposite effects on IFN- $\gamma$ production by human lymphocytes, we first examined the effect of IL-12 on IgE and IFN- $\gamma$ production by IL-4-stimulated PBMC. As seen in Table I, rIL-12 (60 pM) significantly suppresses the production of IgE and increases the synthesis of IFN- $\gamma$ by PBMC cultured in the presence of a saturating concentration of IL4 $(10 \mathrm{ng} / \mathrm{ml})$. IL-4 significantly
Table I. Effects of IL-4 and IL-12 on the Production of IgE and of IFN- $\gamma$ by PBMC

\begin{tabular}{llrrrrr}
\hline & \multicolumn{2}{c}{ Exp. 1 } & & \multicolumn{2}{c}{ Exp. 2 } \\
\cline { 2 - 3 } \cline { 6 - 7 } \multicolumn{1}{c}{ Addition } & IgE & IFN- $\gamma$ & & IgE & IFN- $\gamma$ \\
\hline IL-4 & $<0.2$ & 214 & & $<0.2$ & 62 \\
IL-12 & 57 & $<1$ & & 204 & $<1$ \\
IL-4 + IL-12 & $<0.2$ & 3,364 & & $<0.2$ & 2,800 \\
IL-4 + Control SN & 19 & 1,348 & & 58 & 810 \\
& 61 & $<1$ & & 195 & $<1$
\end{tabular}

PBMC were cultured for $12 \mathrm{~d}$ in the absence or in the presence of IL- 4 $(10 \mathrm{ng} / \mathrm{ml}), \mathrm{IL}-12(60 \mathrm{pM})$, or both. Shown are the mean values of $\mathrm{IgE}(\mathrm{ng} / \mathrm{ml})$ and IFN- $\gamma(\mathrm{IU} / \mathrm{ml})$ measured in four replicate cultures; the variation between the replicates was below $20 \%$. Supernatant fluids from cultures of mock transfected $\mathrm{COS}$ cells (control SN) were used at the same dilutions as the IL-12 containing supernatant fluids.

but incompletely suppresses the IL-12-induced production of IFN- $\gamma$; and, as expected, it totally abolishes the spontaneous production of IFN- $\gamma$. The effects of IL-12 on IgE and IFN- $\gamma$ production are dose dependent, and they are completely overridden by neutralizing anti-IL-12 mAbs (Fig. 1). The production of IgG, IgA, and IgM in IL-4-stimulated cultures is not

A

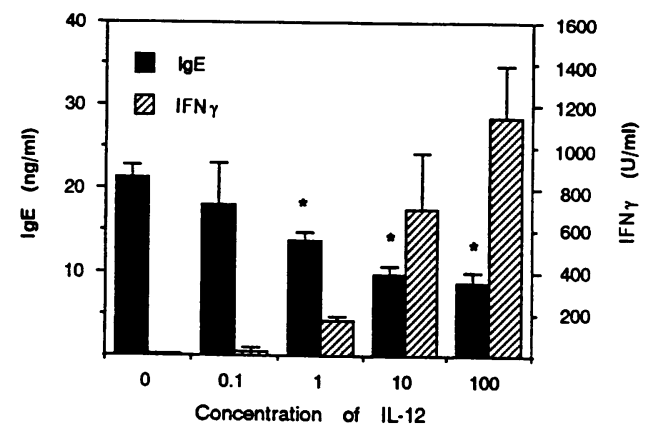

B

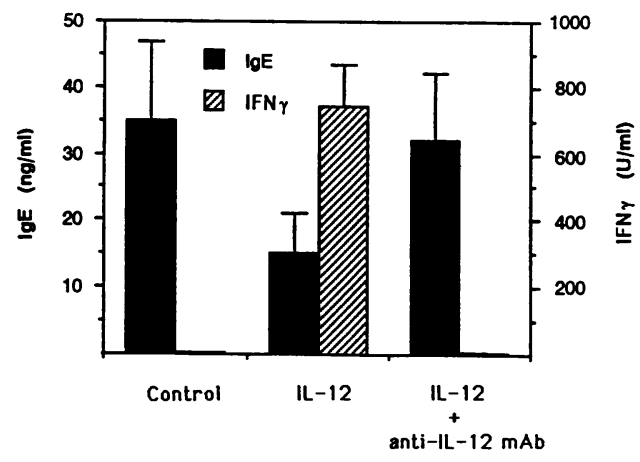

Figure 1. Effect of IL-12 on IgE and IFN- $\gamma$ production by IL-4-stimulated PBMC. $(A)$ PBMC were cultured for $12 \mathrm{~d}$ in the presence of $10 \mathrm{ng} / \mathrm{ml}$ of IL-4 and increasing concentrations of rIL-12 (0.1-100 pM). Shown are the mean \pm 1 SEM of three experiments; *significantly different from control without IL- 12 at $P<0.01$, Student's $t$ test. $(B)$ IL-4-stimulated cultures (control) were supplemented with rIL-12 (60 pM) or with anti-IL- 12 mAbs (a mixture of antibodies $4 \mathrm{Al}$ and $20 \mathrm{C} 2$, each at $10 \mu \mathrm{g} / \mathrm{ml}$ ). Isotype-matched control antibodies (a mixture of rat IgG1 and IgG2b, each at $10 \mu \mathrm{g} / \mathrm{ml}$ ) had no effect (not shown). 


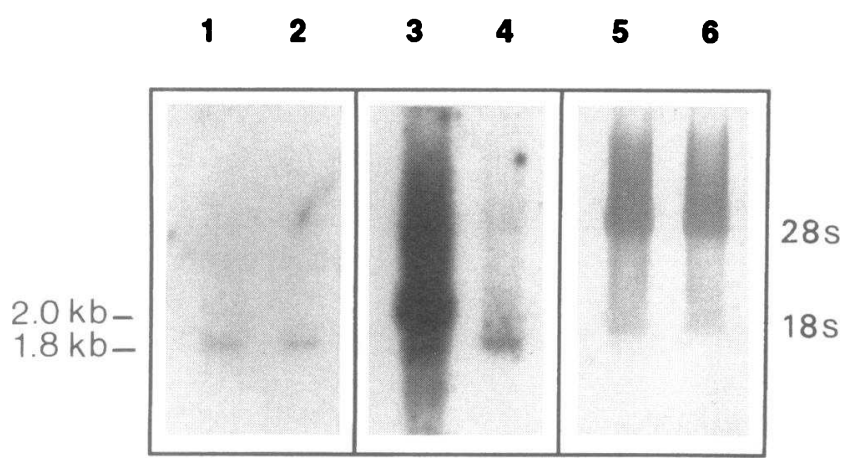

Figure 2. IL-12 suppresses the accumulation of productive but not germ-line $\mathrm{C} \epsilon$ transcripts. Total RNA was extracted from PBMC cultured for $10 \mathrm{~d}$ with $10 \mathrm{ng} / \mathrm{ml}$ of IL-4, in the absence (lanes 1,3 , and 5 ) or in the presence of $60 \mathrm{pM}$ rIL-12 (lanes 2, 4, and 6). Northern blot was performed as described in Methods. The membrane was hybridized with ${ }^{32} \mathrm{P}$-labeled probes specific for the germ-line transcript (lanes 1 and 2) or for the $\mathrm{C}_{1}-\mathrm{C}_{2}$ region binding to both germ-line and mature $C_{\epsilon}$ transcripts (lanes 3 and 4 ). Equal loading was assessed by methylene blue staining of the ribosomal RNA (lanes 5 and 6). IgE production in IL-4-stimulated cultures was of $81 \mathrm{ng} / \mathrm{ml}$, as opposed to $16 \mathrm{ng} / \mathrm{ml}$ in cultures containing both IL- 4 and rIL- 12 .

significantly affected by IL-12 (data not shown). Given that IL-4 does not induce the production IgM, IgA, or IgG (with the exception of IgG4) (4), we next examined the effect of IL-12 in a model where the major classes of $\mathrm{Ig}$ are induced. In three consecutive experiments, rIL-12 (60 pM) had no significant effect on the PWM-induced synthesis of $\operatorname{IgG}(1.6 \pm 0.1$ vs $1.3 \pm 0.6 \mu \mathrm{g} / \mathrm{ml}$; mean $\pm 1 \mathrm{SD}), \operatorname{IgM}(1.2 \pm 0.4 \mathrm{vs} 1.1 \pm 0.6 \mu \mathrm{g} / \mathrm{ml})$ or $\operatorname{IgA}(1.9 \pm 0.6$ vs $2.1 \pm 0.7 \mu \mathrm{g} / \mathrm{ml})$.

To further analyze the IgE suppression by IL-12, we have examined the effect of IL-12 on the accumulation of both mature and germ-line C $\epsilon$ mRNA by IL-4-stimulated PBMC. As shown in Fig. 2, rIL-12 strongly suppresses the expression of the mature but not of the germ-line $C \epsilon$ transcript. These observations demonstrate that IL-12 suppresses the synthesis of IgE, and they further suggest that IL-12 inhibits the switching to $\mathrm{IgE}$. We next examined the possibility to dissociate the IgE suppressive activity of IL- 12 from its IFN- $\gamma$ inducing activity. To this end we have tested the effect of IL-12 on the synthesis of IgE by umbilical cord blood mononuclear cells (CBMC) costimulated with IL-4 and hydrocortisone (HC). These cells were selected because of their impaired capacity to produce IFN- $\gamma$
(23) and because exogenous IFN- $\gamma$ was found to increase rather than to inhibit their synthesis of IgE following stimulation with IL-4 (6). HC was added to IL-4-stimulated CBMC for two reasons: (a) HC inhibits the production of IFN- $\gamma$, even that induced by IL-12 (our preliminary observations); and (b) HC strongly increases the IL-4-stimulated synthesis of IgE, even in the absence of IFN- $\gamma$ production (24). As seen (Table II), rIL12 markedly inhibits IgE synthesis by neonatal cells cultured in the presence of IL-4 plus hydrocortisone and producing little or no detectable IFN- $\gamma$. Moreover, the suppression is unchanged in the presence of a large excess of neutralizing anti-IFN- $\gamma$ $\mathrm{mAb}$. Thus, it appears that IL-12 can inhibit IgE synthesis by a mechanism which is independent of IFN- $\gamma$. This view is consistent with the observation that IL-12 inhibits IgE synthesis by PBMC costimulated with IL-4 and anti-CD40 mAb, a model where IFN- $\gamma$ was reported to be inactive (25). In three such experiments where PBMC were cultured with IL-4 and antiCD40 $\mathrm{mAb} 89(0.5 \mu \mathrm{g} / \mathrm{ml})$, the production of IgE dropped from $70 \pm 28 \mathrm{ng} / \mathrm{ml}($ mean $\pm 1 \mathrm{SD})$ to $20 \pm 8 \mathrm{ng} / \mathrm{ml}$ in the presence of rIL-12 $(60 \mathrm{pM})$, as compared to $79 \pm 35 \mathrm{ng} / \mathrm{ml}$ in the presence of IFN- $\gamma(100 \mathrm{IU} / \mathrm{ml})$. However, IL-12 failed to inhibit the IgE response of highly purified $\mathbf{B}$ cells costimulated with IL-4 and anti-CD40 mAb, $(106 \pm 40 \mathrm{ng} / \mathrm{ml}$ of IgE in the absence of IL-12 as opposed to $123 \pm 73 \mathrm{ng} / \mathrm{ml}$ in the presence of 60 pM IL-12; mean \pm 1 SD of four experiments), indicating that the suppressive effect observed in cultures of unfractionated PBMC is indirect and requires the presence of either $\mathrm{T}$ cells, monocytes, or NK cells.

\section{Discussion}

This study indicates that picomolar concentrations of rIL-12 markedly inhibit the synthesis of IgE by IL-4-stimulated PBMC. The suppression of IgE is observed at the protein and the mRNA levels, and it is completely overridden by neutralizing antibodies to IL-12. Given that the production of IgE by IL-4-stimulated lymphocytes involves the switching of precursor $B$ cells to IgE rather than the selective expansion and differentiation of IgE committed B cells $(4,26)$, the results suggest that IL-12 inhibits the switching to IgE. Consistent with an isotype-specific activity of IL-12, we failed to detect any influence of this lymphokine on the production of the other classes of Ig by IL-4- or by PWM-stimulated PBMC. However, the data do not exclude a possible effect of IL-12 on the production of IgG4, the only human isotype other than IgE that is induced by IL-4 (4). Indeed, IgG4 is produced in much smaller quanti-

Table II. Effect of IL-12 on IgE Synthesis by Neonatal Lymphocytes Stimulated with IL-4 and Hydrocortisone

\begin{tabular}{|c|c|c|c|c|c|c|c|c|}
\hline \multirow[b]{2}{*}{ Addition } & \multicolumn{2}{|c|}{ Exp. 1} & \multicolumn{2}{|c|}{ Exp. 2} & \multicolumn{2}{|c|}{ Exp.3 } & \multicolumn{2}{|c|}{ Exp. 4} \\
\hline & IgE & IFN- $\gamma$ & $\mathrm{IgE}$ & IFN- $\gamma$ & IgE & IFN- $\gamma$ & $\lg E$ & IFN- $\gamma$ \\
\hline - & 373 & $<1$ & 44 & $<1$ & 20 & $<1$ & 302 & $<1$ \\
\hline IL-12 & 6 & $<1$ & 8 & $<1$ & $<0.2$ & 17 & 20 & 33 \\
\hline IL-12 + Anti-IFN- $\gamma$ & 7 & $<1$ & 10 & $<1$ & $<0.2$ & $<1$ & 21 & $<1$ \\
\hline IL-12 + Anti-Lolp1 & 6 & $<1$ & NT & NT & NT & NT & 18 & 128 \\
\hline
\end{tabular}

Umbilical cord blood mononuclear cells were cultured for $12 \mathrm{~d}$ in the presence of IL- 4 and $10 \mu \mathrm{M}$ hydrocortisone. IL-12 (60 pM), anti-IFN- $\gamma$ $\mathrm{mAb}(1,000$ neutralizing $\mathrm{U} / \mathrm{ml}$ ), or the isotype-matched control (anti-Lolpl) $\mathrm{mAb}$ (each at $50 \mu \mathrm{g} / \mathrm{ml}$ ) were added at the initiation of the culture. $\mathrm{IgE}(\mathrm{ng} / \mathrm{ml})$ and IFN- $\gamma(\mathrm{IU} / \mathrm{ml})$ were measured on $\mathrm{d} 12$ and $\mathrm{d} 6$, respectively. Shown are the mean values of quadruplicate cultures; the variation between the replicates was below $20 \%$. 
ties than the other IgG subclasses, so that even a significant inhibition of its production might be overlooked by the RIA used in this study.

IL-12 induces the production of significant amounts of IFN- $\gamma$, even in the presence of a high concentration of IL- 4 that was shown to completely suppress IFN- $\gamma$ production and to induce IgE synthesis in mixed lymphocyte cultures $(6,7)$. This observation not only provides a first mechanism whereby IL12 suppresses the synthesis of IgE, but it also may have other implications. Knowing that IFN- $\gamma$ directs the in vitro as well as the in vivo differentiation of naive $\mathrm{T}$ cells into $\mathrm{TH} 1$ type of cells, it is reasonable to assume that IL-12 may display the same activity even in the presence of IL-4, which may also be produced by non-T cells (27). According to this view, IL-12 might play a role in determining the outcome of the immune response to certain antigens or pathogens that are known to preferentially generate $\mathrm{TH} 1$ or $\mathrm{TH} 2$ helper cells. The cellular origin of IL-12 is consistent with a putative role of this lymphokine in the differentiation of naive T cells. Indeed, IL-12 may be produced not only by Epstein-Barr virus transformed B cells, from which it was isolated, but also by normal B cells (our unpublished observations) that are known to be efficient antigen-presenting cells. The availability of recombinant mouse IL12 should permit the examination of these possibilities in vivo (28).

In preliminary experiments using neutralizing antibodies to IFN- $\gamma$ we failed to consistently overcome the IL-12 mediated suppression of IgE synthesis by adult PBMC. Although these negative results may be easily explained by: $(a)$ the relatively high levels of IFN- $\gamma$ in IL-12 containing cultures; and $(b)$ the difficulty to block the biological activity of endogenously produced IFN- $\gamma$, they prompted us to examine whether IL-12 may also suppress IgE by another mechanism which is IFN- $\gamma$ independent. The existence of such a mechanism is demonstrated by the ability of IL-12 to markedly inhibit IgE synthesis by IL-4 and hydrocortisone-costimulated neonatal lymphocytes which do not produce detectable amounts of IFN- $\gamma$. The possibility that such undetectable levels of IFN- $\gamma(<1 \mathrm{IU})$ might nevertheless account for the suppression of $\operatorname{IgE}$ is most unlikely given that a very large excess of neutralizing anti-IFN$\gamma$ antibody failed to increase the IgE response. Two other observations are consistent with the notion that IL-12 mediated suppression of IgE does not only involve the induction of IFN$\gamma$. First, comparing our results on the accumulation of germline and mature IgE mRNAs with those of a recent study (5) reveals that whereas both IL- 12 and IFN- $\gamma$ markedly suppress the accumulation of productive $\mathrm{C} \epsilon$ mRNA in IL-4-stimulated PBMC ( $>90 \%$ suppression), IFN- $\gamma$, but not IL-12, also suppresses the expression of germ-line transcript (50-70\% inhibition). Second, we observed that IL-12 suppresses IgE synthesis by PBMC costimulated with IL-4 and anti-CD40 mAb, a model where IFN- $\gamma$ is known to be inactive (25). In this case, however, the effect of IL-12 is indirect and requires the presence of either T cells, monocytes, or NK cells, as evidenced by the failure of IL-12 to block IgE synthesis by highly purified B cells costimulated with IL-4 and anti-CD40 mAb. Although the mechanism whereby IL-12 inhibits IgE synthesis in the absence of IFN- $\gamma$ production is still under investigation, the present results suggest that, like the interferons, IL-12 may not only play an important role in protective immunity, but also in the regulation of isotype selection.

\section{Acknowledgments}

We express our gratitude to Dr. R. Geha for providing the C $\epsilon$ probes, to Dr. J. Banchereau for the anti-CD40 mAb, and to Dr. H. Hofstetter for the rIL-4. We wish to thank Chantal Fonteyn-Rubio for technical assistance, and Norma Del Bosco for her excellent secretarial assistance.

G. Delespesse is an Medical Research Council (MRC) Associate. This work is supported by an MRC grant.

\section{References}

1. Finkelman, F. D., J. Holmes, I. M. Katona, J. F. Urban, Jr., J. P. Beckmann, L. S. Park, K. A. Schooley, R. L. Coffman, T. R. Mosmann, and W. E. Paul. 1990. Lymphokine control of in vivo immunoglobulin isotype selection. Annu. Rev. Immunol. 8:303-333.

2. Snapper, C. M., and W. E. Paul. 1987. Interferon- $\gamma$ and B cell stimulatory factor-1 reciprocally regulate $\mathrm{Ig}$ isotype production. Science (Wash. DC). 236:944-947.

3. Pene, J., F. Rousset, F. Brière, I. Chrétien, J. Y. Bonnefoy, H. Spits, T. Yokota, K. Arai, J. Banchereau, and J. de Vries. 1988. IgE production by normal human lymphocytes is induced by interleukin-4 and suppressed by interferons $\gamma$ and $\alpha$ and prostaglandin E2. Proc. Natl. Acad. Sci. USA. 85:6880-6884.

4. Gascan, H., J.-F. Gauchat, M.-G. Roncarolo, H. Yssel, H. Spits, and J. E. deVries. 1991. Human B cell clones can be induced to proliferate and to switch to IgE and IgG 4 synthesis by interleukin 4 and a signal provided by activated CD4 ${ }^{+}$ T cell clones. J. Exp. Med. 173:747-750.

5. Gauchat, J.-F., D. A. Lebman, R. L. Coffman, H. Gascan, and J. E. deVries. 1990 . Structure and expression of germline $\epsilon$ transcripts in human B cells induced by interleukin 4 to switch to IgE production. J. Exp. Med. 172:463-473.

6. Peleman, R., J. Wu, C. Fargeas, and G. Delespesse. 1989. Recombinant interleukin 4 suppresses the production of interferon $\gamma$ by human mononuclear cells. J. Exp. Med. 170:1751-1756.

7. Vercelli, D., H. H. Jabara, R. P. Lauener, and R. S. Geha. 1990. Interleukin-4 inhibits the synthesis of interferon- $\gamma$ and induces the synthesis of IgE in mixed lymphocyte cultures. J. Immunol. 144:570-576.

8. Coffman, R. L., K. Varkila, P. Scott, and R. Chatelain. 1991. Role of cytokines in the differentiation of $\mathrm{CD}^{+} \mathrm{T}$-cell subsets in vivo. Immunol. Rev. 123:189-207.

9. Gajewski, T. F., and F. W. Fitch. 1988. Anti-proliferative effect of IFN- $\gamma$ in immune regulation. I. IFN- $\gamma$ inhibits the proliferation of TH2 but not TH1 murine helper T cell clones. J. Immunol. 140:4245.

10. Fernandez-Botran, R., V. M. Sanders, T. R. Mosmann, J. W. Uhr, and E. S. Vitetta. 1988. Lymphokine-mediated regulation of the proliferative response of clones of TH1 and TH2 cells. J. Exp. Med. 168:543-548.

11. Scott, P. 1991. IFN- $\gamma$ modulates the early development of TH1 and TH2 responses in a murine model of cutaneous leishmaniasis. J. Immunol. 147:31493155 .

12. Finkelman, F. D., A. Svetic, I. Gresser, C. Snapper, J. Holmes, P. P. Trotta, I. M. Katona, and W. C. Gause. 1991. Regulation by interferon $\alpha$ of immunoglobulin isotype selection and lymphokine production in mice. J. Exp. Med. 174:1179-1188.

13. Gubler, U., A. O. Chua, D. S. Schoenhaut, C. M. Dwyer, W. McComas, R. Motyka, N. Nabavi, A. G. Wolitzky, P. M. Quinn, P. C. Familletti, and M. K. Gately. 1991. Coexpression of two distinct genes is required to generate secreted bioactive cytotoxic lymphocyte maturation factor. Proc. Natl. Acad. Sci. USA. 88:4143-4146.

14. Wolf, S. F., P. A. Temple, M. Kobayashi, D. Young, M. Dicig, L. Lowe, R. Dzialo, L. Fitz, C. Ferenz, R. M. Hewick, et al. 1991. Cloning of cDNA for natural killer cell stimulatory factor, a heterodimeric cytokine with multiple biologic effects on T and natural killer cells. J. Immunol. 146:3074-3081.

15. Kobayashi, M., L. Fitz, M. Ryan, R. M. Hewick, S. C. Clark, S. Chan, R. Loudon, F. Sherman, B. Perussia, and G. Trinchieri. 1989. Identification and purification of natural killer cell stimulatory factor (NKSF), a cytokine with multiple biologic effects on human lymphocytes. J. Exp. Med. 170:827-845.

16. Gately, M. K., B. B. Desai, A. G. Wolitzky, P. M. Quinn, C. M. Dwyer, F. J. Podlaski, P. C. Familletti, F. Sinigaglia, R. Chizonnite, U. Gubler, and A. S. Stern. 1991. Regulation of human lymphocyte proliferation by a heterodimeric cytokine, IL-12 (cytotoxic lymphocyte maturation factor). J. Immunol. 147:874882.

17. Chan, S. H., B. Perussia, J. W. Gupta, M. Kobayashi, M. Pospisil, H. A. Young, S. F. Wolf, D. Young, S. C. Clark, and G. Trinchieri. 1991. Induction of interferon $\gamma$ production by natural killer cell stimulatory factor: characterization of the responder cells and synergy with other inducers. J. Exp. Med. 173:869879. 
18. Rousset, F., E. Garcia, and J. Banchereau. 1991. Cytokine-induced proliferation and immunoglobulin production of human B lymphocytes triggered through their CD40 antigen. J. Exp. Med. 173:705-710.

19. Sarfati, M., and G. Delespesse. 1988. Possible role of human lymphocyte receptor for $\mathrm{IgE}(\mathrm{CD} 23)$ or its soluble fragments in the in vitro synthesis of human IgE. J. Immunol. 141:2195-2201.

20. Chizzonite, R., T. Truitt, F. J. Podlaski, A. G. Wolitzky, P. M. Quinn, P Nunes, A. S. Stern, and M. K. Gately. 1991. IL-12: Monoclonal antibodies specific for the 40-kDa subunit block receptor binding and biologic activity on activated hyman lymphoblasts. J. Immunol. 147:1548-1556.

21. Peleman, R., and G. Delespesse. 1990 . In vitro synthesis of human IgE by neonatal lymphocytes: enhancing effect of interferon- $\gamma$. Cell. Immunol. 129:299309.

22. Jabara, H. H., L. C. Schneider, S. K. Shapira, C. Alfieri, C. T. Moody, E. Kieff, R. Geha, and D. Vercelli. 1990. Induction of germ-line and mature $C_{\epsilon}$ transcripts in human B cells stimulated with rIL-4 and EBV. J. Immunol. 145:3468-3477.

23. Kibler, R., M. J. Hicks, A. L. Wright, and L. M. Taussig. 1986. A compara- tive analysis of cord blood and adult lymphocytes: interleukin- 2 and interferon production, natural killer cell activity, and lymphocyte populations. Diagn. Im munol. 4:201-208

24. Wu, C. Y., M. Sarfati, C. Heusser, S. Fournier, M. Rubio-Trujillo, R. Peleman, and G. Delespesse. 1991. Glucocorticoids increase the synthesis of immunoglobulin $\mathrm{E}$ by interleukin 4-stimulated human lymphocytes. J. Clin. Invest. 87:870-877.

25. Zhang, K., E. A. Clark, and A. Saxon. 1991. CD40 stimulation provides an IFN- $\gamma$-independent and IL-4-dependent differentiation signal directly to human B cells for IgE production. J. Immunol. 146:1836-1842.

26. Vercelli, D., and R. S. Geha. 1991. Regulation of IgE synthesis in humans: A tale of two signals. J. Allergy Clin. Immunol. 88:285-295.

27. Plaut, M., J. H. Pierce, C. J. Watson, J. Hanley-Hyde, R. P. Nordan, W. E. Paul. 1989. Mast cell lines produce lymphokines in response to cross-linkage of FceRI or calcium ionophores. Nature (Lond.). 339:64-66.

28. Schoenhaut, D., A. Chua, A. Wolitsky, P. Quinn, C. Dwyer, M. Gately, and U. Gubler. 1992. Cloning and expansion of murine IL-12. J. Immunol. In press. 